State Board of Iealth, which limits the time within which such discharge can continue, and the remaining fourtcen represent the number of cities and towns whose systems were in existence previous to the passage of the law relative to the pollution of streams, and whose privilege has not since been modified.

In more recent years, while the advisory policy with reforence to the control by the state over its inland waters has been continued, this policy las been materially strengthened by inserting in each new act passed by the lecrislature authorizing the introduction or modification of srstems of water supply, drainage or scwerage, a clause requiring the approval of the plans by the State Board of Health.

As a result of the legislation of 1886 and the subsequent acts strengthening that legislation, the pollution of streams by the sewage of cities and towns has been arrested, and progress has been male in reclaiming from pollution some of the streams which had already brcome seriously injured at the time the act was passed. There still remain, however, several cases of serious stream pollution in Massachusetts by the sewage of cities and towns, most of 'which, howcver, are already in process of removal.

In dealing "with the pollution of streams in Massachusetts one of tlie most scrinus problems presented has been that of the Neponset river, a stream which has been grosely polluted almost wholly by wastes from manufilcturing processes in tanneries, paper mills, woolen mills, gas works, etc. All, or practically all, of these establishments were in cxistence at the time the laws relating to the pollution of streams were passed; in fact, in many cases, these manufactories had been in operation for many years.

In this case the question of preventing the nuisance caused by the stream was brought to the attention of the legislature, which directed the State Board of Health to investigate the causes and recommend measures for proventing the trouble. The question was complicated by a question of the drainage of extensive marsh lands along the stream, and the whole matter was the subject of consideration by the legislature for five successive vears before action was finally taken. The law then passed did not prove strong enough to secure satisfactory results, and after four years of trial a law was finally paseced requiring the purification of the manufacturing wastes by all persons discharging such wastes into the stream or any of its tributaries under penalty of a heavy finc for neglect to observe its provisions. Under this act, which was passed last year, manufacturers have quickly taken steps to prevent their wastes from creating further offense in the stream.

It is important, before closing, to call attention to one other and most essential factor in carring out suecesfully the work of preventing the further pollution of streams in Massachusetts and recovering the ground which had already been lost there when this work was first undertaken, and that is the provision made by the legislature which authorized the State Board of Health to make experiments on the purification of sewage and manufacturing wastes so that the board might be in a position to advise cities, towns and manufacturers as to the most appropriate and satisfactory methods of disposal or purificaton of such wastes.

Very soon after the passage of the law an experiment station was established by the board at Iawrence, and experiments have been made there continuonsly for the last twenty years on the purification and disposal of sewage, and of all kinds of manufacturing wastes, besile the work lone there in the purification of water and $i_{n}$ other investigations in connection with the rork of the board on this and similar subjects.

At this experiment station were made the first systematic investigations on the purification of sewage on a practical scale, the results of which have been the basis of the adrice of the board in dealing with problems relating to the prevention of the pollution of streams.

The results of these experiments and investigations neel not be considered here, further than to state that ther lave stood the test of many rears in the purification of the sewage or other wastes of a large number of citics, towns and manufacturing establishments.

\section{SEWAGE PURIFICATION BY SEPTIC TANK AND CHEMICAL PRECIPITATIOA.*}

\author{
GEORGE T. MOORE:, PIS. T). \\ WASIIX(TTOX, 1). (:
}

The obvious impossibility of discussing in any rletail either the septic tank or chemical treatment of swage, in the twenty or thirty minutes allotted, makes it necessary that the subject lie treated very generally, depeniing on the discussion which may follow to bring ont special points of interest. Fortunately, the saticfactory account of these two methods of sewage disposal girein by Jrofessor Winslow and Mr. Phelps in No. 18.5 of the Viater Supply and Irrigation Papers of the U. S. Genlogical Surver makes it unnecessary to devote any time either to the theoretical or historical side of the subject, and, therefore, the practical aspect will be the only one touched.

The two extreme views now leld in this country regarding sewage disposal may be represented, on the one liand, by those who hold that all water for domestic purposes must be purified and consequently there is no need of rasting time and money on sewage; ant. on the other hand, by some authorities who claim it is an al)surdity to have to repurify water deliberately polluten, and that the solution of the pure-water problem lics in the most rigit and efficient purification of sewage and other wastes which by any natural means can reach a properly protected water supply. It is evident. without attempting to indicate the difficulties which must attend the proper enforcement of either of these plans alone, that for the present at least the only safe method is to purify both water and sewage whenever practicable, anil the discussion in this country in legislative halls. as well as before scientific associations, regarding proper seware disposal, would scem to indicate that to provide such a doulle safeguard may not be as impossible as was at once supposed.

It will probably be admitted that the question of sewage risposal is quite distinct from that of water purification both from the standpoint of the public, as well as that of the engineer and biolngist. Tsulal!r when a community is forced to the sanitary consideration of its sewage problem it is for the benefit of some other town in the vicinity, and the interest can never be such a lively one as that concerned with the procuring of a pure water for local consumption. A town which would not hesitate to spend a million for pure water absolutely refuses to devote one-tenth of that amount for sewage purification. Within the last year a

* Read in the Soction on Hygiene and Sanitary Science of the

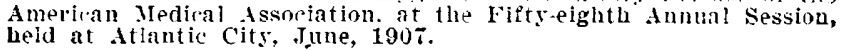


community with which I was associated overwhelmingly voted down the proposition to borrow the $\$ 250,000.00$ necessary to install an efficient and modern sewage disposal plant. 'This, too, in the face of threats from the state health officer and several pending suits from individuals through whose property the stream of sewage flowed. It is interesting to note that an analysis of the vote showed that the proposition was defeated not by the property owners and better class of citizens on whom the immediate cost would have fallen, but on the s!nall renter who seemed to have the jdea that the expenditure of so much money for sewage disposal would increase his rent and other living expenses.

Thus it would seem that there now exists a necessity for the perfection of methods which, while in themselves not altogether ideal, will afford some relief and to a considerable extent answer the purpose of purifying sewage. For. although there are a few shining examples of cities willing to spend the time and money necessary to find the bost, we are not ret at the stage in this country where we can hope to convert the average community to this practice.

Furthermore, the efficient and economical disposition of sewage is vastly more dependent on local conditions than that of the purification of water. We certainly are not now at the place where any single method of treating sewage can be unitersally recommended, and, even though there might be agreement on the best theoretical means of accomplishing this purpose, the chances are that metlods quite fistinct must akways be used to meet peculiar or even common conditions.

While most authorities on sewage disposal maintain that the problem of purification does not involve the question of a sterile effluent, there can be no doubt that the legal interpretation of what a purified sewage should be has been for the most part opposed to this view. And since, at the present time, the strongest incentive to any community to properly dispose of its sewage is the threatened damage suit of a neichboring town, some attention should be paid to the prorluction of an effuent that will meet the requirements of the law. Certainly to the lay mind any method incapable of insuring an effluent free from ilisease germs would seem, to that extent at least inefficient.

The septic tank method of treating semage is generally used in combination with one of several other processes, merely the preliminary breaking down of the organic matter being accomplished in the tank. For purposes of this discussion, however, it will probably be well to dwell more particular]y on the results obtained from the septic tank alone, with only a brief reference to the sulsequent treatments with which it is used in combination.

A septic tank, as you no doulst know, is simply a suitable receptacle in which raw sewage may be confined for a lengtl of time sufficient to permit the bacteria naturally present to decompose the solid matter, as well as much that is already in solution, or comes into solution as the result of the decomposition. This time varies according to the character and age of the sewage, the temperature, etc., and may be as short as four hours or as long as forty-eight hours. Longer periods of treatment do not seem to have the beneficial effect that might be expected. The tanks may or may not be covered, they may be proviried with preliminary grit clsambers, and mav have various automatic devices to control the flow of the sewage, lout the principle inrolved is the same in all cases, and any condition which will per- mit the most active growth of the decomposing bacteria is the one most desired.

There are comparatively few places in which the septic tank with no subsequent treatment has been resorter to. Indeed, the septic tank alone can hardly be considered as a means of disposing of sewage, as the effluent will frequently come under a technical definition of sewage as truly as that which flowed into the tank. The phrsical character of the sewage is usually greatly improved, however, and its discharge directly into a stream is permitted under conditions which would make such a disposition of the raw sewage impossible. The chicf function of the septic tank is to reduce the sludge. One properly constructed can generally be counted on to take out over 50 per cent. of the suspended soids, sometimes as high as 75 per cent. There is the greatest variation regarding the retention of the stored solids, and one objection which has been urged against the use of the septic tank has been the frequency with which it has to be cleaned. There seems to be reason for believing, however, that such an objection may not be overcome when the conditions on which the optimum efficiency of a septic tank depends are better understood. Certainly the great difference in tanks which have to be cleaned every few months as compared with those which have run for years without being emptied is not due entirely to the difference in the character of the sewage. There is probably no method which can be depended on to remove such a high percentage of the suspended solids, at such small expense, as the septic tank, particularly in the many localities in this countrv where neither land nor suitable sand or gravel can le obtained for some of the other processes. On the whole, howerer, the septic tank method alone is not one to be recommended, although, in the case of very small communities or of institutions, it mav be resorter to as a stepping stone to something better. Being cheap and requiring comparatively little attention, it is more apt to be adopted than a more efficient and complete trpe of sewage disposal. While it is to be hoped that the septic tank alone as a means of treating sewage will not be tolerated ten years hence, we are hardly at the place where we can afford to discourage any effort which must in a short time tend to develon more satisfactory and thorough means of solving a difficult problem.

The most common method of using the septic tank is as a preliminary treatment, the effluent being suhsequently passed through some sort of filter or contact bed. It does not come within the scope of my subject to discuss the various methods which have been derisod for treating the effluent from the septic tank, but the fact that this is the almost universal practice emphasizes the point that septic tank treatment alone can not be considered as one-properly disposing of a sewage.

In England as well as in this country the use of the septic tank, combined with some system which would permit of the action of oxidizing bacteria, has given most excellent results, and the failures seem to be rlue to mismanagement rather than to anv fault in the method. Throughout the middle west, where conditions are not so favorable for intermittent filtration, the septic tank is most successfully combined with a contact bed, and the good results obtained would seem to indicate that the possibilities of this combination are by no means exhausted. The septic tank then may be considered as a most important and in some cases necessary preliminary method of treating sewage, which, in conjunction with a contact bed or filter, is capable under proper 
management of prolucing an affuent which meets the requirements of many communities at the present time. It is not a sterile effluent, however, and it would appear that conditions in this country may in the future require still further treatment before a thoroughly satisfactory effluent is obtained.

One of the oldest methods of attempting to dispose of sewage is by the use of chemicals. In this country possibly 10 per cent. of those cities making an effort to treat their sewage in a sanitary manner use a chemical precipitation method. In Europe, on the other hand, chemicals are widely used, and although newer methouls are being experimented with and installed, there are a considerable number of authorities who cling to chemieal precipitation as being best suited to meet their special conditions.

While the number of chemical combinations and devices for using them in treating sewage are too numerous to mention, practically the only ones used on a large scale at the present time are those depending on lime, with either sulphate of alumina or sulpluate of iron as precipitants. In this country sulpluate of iron with lime is used almost exclusirely. That a satisfactory efluent can be obtained by properly treating sewage with chemical precipitants has never been deniof. Br using a sufficient amount of lime and iron sulphate and allowing proper time for sedimentation the resulting effluent is msually all that could be desired. Ill odors and tastes are removed, and by combining the use of copper sulphate or chlorid of lime the samp?es taken have been found to be free from colon bacilli and all similar organisms.

The chice and most serious oljiection to anr chemiral precipitation method has been the cost. For, in addition to the original cost of the chemicals, the disposal of the resulting sindge adds considerably to the expense of the operation. In some instances the wastes may run as higl as fifty tons per million gallons of sewace. althoigh in many cases it is not more than half this amount. While it is true that a very large percentage of the sludere is water, it requires consir?erable time and money to get the water out, and the "press-cake" is at present of little if any value. When some one devises a profitable use for the sludge from chemical precipitation the chances are that the method will be more widely employed.

Some cities scem to be especially well adapted by natural conditions to use the chemical precipitation method of sewage disposal. Worcester, Mass.. is a well-known example of a town having enough sulphate of iron from factory waste in its sewage to need only the addition of lime to form a proper coagulum. Providence, R. I.. is another instance of a city using chemicals with satisfactory results, and while here it is the natural situation which makes the system so successful, there are other places in this country so situated which might do well to substitute a similar chemical precipitation plant instead of turning the raw sewage directly into the sea. There are likewise institutions and factories where the waste is of such a character as to practically necessitate a chemical treatment. The expense, of course, is larre, and probalbly no city would be justified in spending such an amount, but the point is there exist special conditions for which chemical precipitation methods should probably always be used. Certainly the method should not be neglected at the present time simply hecause it is not universally adapted to all conclitions in all parts of the country.
111 metlonls of sewage purification may be said at the preint time to be more or less in the experimental stage, at least when attempting to adapt them to changed local conditions. Chemical precipitation, in spite of the large amount of work done with it in the past, is being widely tested and experimented with along some now and interesting lines. What the outcome may be no one can say, but that the chemical methot of seware disposal, just as the chemical method of water purificition. may not become more popular and be used more generally in those localities where it is applicable is not improbable.

Another use to which chemicals have been more rocontly put in ennection with sewage purification, aur which may not be improperly discused here, is that of a gernicide rather than a precipitant. As- has been previously said, the necessity of having the efluent from a sewage disposal plant sterile, at least so far as pathogenic organism is concerned, is becoming more ant more apparent, and it would seem that such a result could be best and most satisfactorily obtained by the use of certain chemicals.

It present those most frequently employed are eithur copper sulphate or chlorid of lime, and it would applar from results already obtained that a sterilized efflucnt can he readily and cheaply obtained by some such means. Of course the application of chemicals as germiciles should usually be made after the sewage has heen oxidized to a non-putrescible condition by any one of the methods best adapted to the local situation. Fxperiments have been made with lime. iron sulphate and copper which produced most satisfactory results, but it remains to be seen how general the application of such a method may become. Copper sulphate has likewise been added to sewage before it went on to the filter bets. and a great reduction in coli over the untreated sewaye psulterl. But it would appear that for many reasons the time to add a germicile is after the sewage is oxidizat rather than before.

As was plainly pointed out by Mr. Kellerman and mysulf in discussing tlo use of copper as an aloicide and germicide for water supplies, and somewhat needlessly reiterated by subsequent workers, the effect of laro? quantitics of organic matter on copper is to throw it out of solution and thus greatly reduce its toxic propcrty. For this reason copper hardly scems to be the germicide best suited for use in a sewage efluent. Fxperiments with calcium hypochlorite have shown that chlorin is not so rapidly affected by the oroanic matter, and consequently, in hard waters at least, is much more efficient. as well as cheaper.

Tndependent results obtained by experimenters in different parts of the country and with different kinds of waters indicate that br using chlorid of lime sufficient to give from one to five parts arailable chlorin at least 99.9 per cent. of the total bacteria in a sewage effluent can be removed and cren a higher percentage of fermenting organisms.

The figures for the use of copper sulphate under.sim. ilar circumstances are not nearly so good, particularly in the west where hard waters are the rule. Under such circumstances it required from five to ten parts $\mathrm{per}$ million to remove from 90 to 95 per cent. of the total bacteria, although in the east with soft waters Phe ps was able to obtain a reduction of 94 per cent. total organisms and 98.5 of fermenting forms with one part per million of copper at a mean temperature of 50 degrees. Of course as the temperature lowers the efficiency 
is reduced, and at 43 degrees it was necessary to use two jarts per million to get an efficiency of $9 \% .9$ per cent. for the total organisms and 98.8 per cent. for the fermenting forms. In general, it may be safely concluded that chlorid of lime is superior to copper sulphate as a germicide for sewage eflluents, both on account of efficiency and cheapness, although under special conditions, with soft water and rather high temperatures, it may be that copper would be more suitable. It is certainly more convenient to use.

To sum up, it would appear then that the septic tank, under ordinary conditions where there are no trade wastes calculated to retard bacterial action, is well suited to remove a considerable percentage of the suspended matter in sewage. It requires a small amount of space, can be cheaply operated, and the difficulty of disposing of the stored matter can probably be readily overcome. 'There seems to be no reason why careful attention to the time sewage is in the tank, with probably some minor changes in construction. should not enable such a system to rum for ycars without being cleaned. The septic tank should not, howercr, be considered in itself a complete method of properly disposing of sewage, but should be followed by some process which will expose the effluent to further bacterial action in order that the result be what it should.

Until recently the chemical treatment of sewage, like the chemical treatment of waters, has been decidedly out of vogue in most places in this country. Within the past few years. however, interest has been revived in the method, and further investigations and improvements in treating sewage chemically may result in its being used more extensively than formerly. 'That it is well adapted to handle certain conditions is recognized; whether it is to have a wider application remains to be seen. If conditions change so that authorities demand a sterile as well as an oxidized eflluent from sewage disposal plants it is not unlikely that it will be found that such results can be as cheaply and satisfactorily obtained by combining a germicide with chemical precipitation methods as in other ways which would have to be resorted to. In any case, it would seem that the use of chlorin or copper for sterilizing the effluent from any ocwage disposal plant is likely to come into more general use.

As was said in the first place, the prohlem of sewage disposal is one which calls for the greatest amount of adaptation to local conditions, with no single type suitable to all. Under such circumstances we can not afford to be governed by preconceived ideas or prejudice. Wherever possible actual experiments should be conducted with all feasible methods on a large enough scale to actually determine for a given locality the best means of disposing of its sewage. If this is not possible certainly no system should be adopted until after the most careful and thorough investigation by experts uncommitted to any special type. There have been too many examples in the past of installing or rejecting a septic tank or intermittent filters or chemical treatment sinply bècause they succeeded or failed some place else. Let us realize that the question of sanitary sewage disposal is often much more complicated than that of a pure water supply and not fail to give the mitter the consideration which it deserves and demain...

Education in the Country.-The old-time notion to place colleges in the wools was correct, and the present tendency to reverse Nature and graduate a stream of blond city neuras. thenies to become educated paupers is a disaster.-Amer. Med.
FACIORS IN THE PRODUCTION OF COAGULA. TION NECROSIS.*

D. H. BERGEY, M.D.

Assistant Professor of Hacreriology, Lniversity of rennsylvania. PIILADELIHIA.

Coagulation necrosis is usually defined as that form of death of tissue in which the proteid suffers change similar to or identical with coagulation. It is known that this condition can be induced by varions chemical substances, as acids, alkalies, and metallic salts; by some of the alkaloids; by vegetable poisons, as ricin and abrin; and by bacterial poisons. In addition to tlise caluses it has been suggested that ferments derived from the body cells may, under certain conditions, produce similar effects as in the case of anemic infarcts of the spleen and lidney.

It seemed probable that additional information could be gained of the factors underlying coagulation necrosis by studying the factors underlying the coagulation of culture media, containing blood serum, through bacterial agencies, as well as by experiments upon animals.

A study of the factors underlying the coagulation of blood serum in the form of the weil-known firs meilia through the agency of bacteria has shown that this effect is brought about by the organic acids produced in the fermentation of the carbohydrates in the media. and a coagulating enzyme produced by the bacteria. The neutralization of the acid in the cultures by means of calcium carbonate (marble) inhibits the coagulation of the media, indicating that the acid is an important factor in the process.

When bacteria are cultivated in bouillon containing dextrose and afterward the cultures are filtered through a Berkefeld filter, these filtrates when added to sterile, Hiss media act in a manner similar to, if not identical with, the living organisms. The filtrates induce typical clotting of the media and in this respect their action differs from the action of dilute acids of equal acidity; the dilute acids inducing merely precipitation of the albuminous constituents of the media. The action of the filtrates is also entirely inhibited on neutralization of the acids contained in them. while boiling inhibits the coagulation but does not inhibit the precipitation of the media.

From these facts it seems evident that the coagulation of the blood serum by living bacteria, or by means of culture filtrates, is induced by the combined action of the organic acids and coagulating enzymes produce 1 by the bacteria. In fact, it was possible, by using tise method suggested by Conn, to recover the coagulating enzyme from the culture filtrates and obtain identical results with solutions of these enzymes. The concillsion that I have reached on the basis of these studies is that blood scrum is coagulated outside the borly through the agency of bacteria by altering the electric charge of the colloids in the serum through the combined action of the organic acids and the coagulating enrymes which they produce.

In order to ascertain the influence of bacteria in produeing coagulation necrosis and other alterations of the colloirls in the body, two lines of experimentation were pursued: (1) The inoculation of animals with livin? cultures and the simultaneous administration of weak alkalies in an attempt to neutralize the acids formed by the bacteria through fermentation of the carlos.

* Read in the Section on Pathology and Phrsiology of the American Medical Association. at the Fifty-eighth Annual Session, held at Atlantic City, June, 1907. 